\title{
EUGENICS BETWEEN SCIENCE AND POLITICS IN LATVIA DURING WORLD WAR II: THE INVESTIGATION FILE OF THE MINISTRY OF STATE SECURITY OF THE LATVIAN SSR IN THE CASE OF THEODOR UPNERS
}

\author{
Uldis Krēsliṇ̆ \\ Department of 20th Century Research \\ of Institute of Latvian History at the University of Latvia, \\ Riga, Latvia
}

\begin{abstract}
This study, based on the materials of the 1948 investigation of the Ministry of State Security of the Latvian SSR, traces and analyzes the scientific and administrative activities of Theodor Upners (1898-1992) during the Nazi occupation regime in Latvia. From 1942 until the end of the occupation in 1944, Upners was formally the leading eugenics specialist in Latvia. During this time, in 1942 he visited Germany on a scientific trip, gave a course on eugenics at the University of Riga, and in 1943 published the book "The Role of Eugenics in the Life of the Nation and the State". In the 1948 investigation, he was accused of collaborating with the Nazi occupation authorities and glorifying Nazi racial theory. The materials of the investigation indicate that the Upners' Case was, at least in part, an episode of the repressions towards genetic that began in the Soviet Union. Upners acknowledged his collaboration with the Nazi occupation authorities, but denied - and this is confirmed by his published work - the glorification of racial theory and any calls for racial hygiene. Upners continued to fight to have these charges dropped until his rehabilitation in 1990. In this study, analyzing Upners' activities during the Nazi occupation in the range between collaboration and resistance, against the background of his story, it is argued that the ideas of Nazi racial hygiene did not find support and adherents among Latvian academic scientists, and the rare public speeches about racial superiority were a tribute to political interests of the occupation regime.

Keywords: Upners, Eugenics, Latvia, Nazi Occupation Regime, Racial Hygiene, Lysenko
\end{abstract}

\section{Introduction}

On 2 July 1948 the Ministry of State Security (Ministerstvo gosudarstvennoj bezopasnosti - MGB) of the Latvian SSR, considering the materials received at its disposal, arrested Theodor Upners (1898-1992), the head of the Department of Neurological Diseases of the State Clinical Hospital and a former researcher at the Institute of Biology and Experimental Medicine at the Latvian SSR Academy of Sciences. He was accused of collaborating with the Nazi occupation regime and promoting the ideas of 'pseudoscience' eugenics. The aim of given study is to critically analyze Upners' judgments about his scientific activities and role in the politics of the Nazi occupation regime in Latvia by the materials of the Investigation file of the MGB of the Latvian SSR. In the situation when Upners had formally become the leading Latvian eugenics specialist in 1942, finding out his position and efforts is essential. This would make it possible to characterize the participation and role of Latvian physicians and scientists in the implementation of the racial policy of the Nazi occupation regime in Latvia as a whole, as well as highlight the main contradictions in opinions in its implementation. In order to gain a fuller understanding of Upners' own views, the study briefly traces his life, as well as his persistent efforts to achieve his rehabilitation during the Soviet period. Finally, one more research task solved in this study is to show the view of the Soviet authorities on the ideas of eugenics, formulated in the materials of the Investigation file, and the development of this view in the post-war years.

\section{Sources and literature used}

The main source used in the study is the Investigation file of the MGB of the Latvian SSR, which is located in the Latvian State Archives of the Latvian National Archives (LNA LSA). The file covers the period from the beginning of the investigation in 1948 to Upners' rehabilitation in 1990. In addition to the protocols of the interrogations of Upners and various witnesses, the texts of articles and scientific papers published by Upners are also attached in the file materials as material evidence. Of course, given the weakly veiled ideological view of the 1948 investigation, as well as Upners' understandable subjectivity and several chronological inaccuracies in his testimony, the materials of this file require a critical approach. However, the main feature of this Case is that during the 1948 investigation, Upners sometimes gave testimonies in which he slandered himself. A striking example of this is Upners' testimony in 1948 about an interview with the newspaper "Têvija" ("Fatherland") in 1942, in which, according to him, he called on Latvians to follow the example of 'Greater Germany' in the field of eugenics and racial segregation. ${ }^{1}$ In fact, his only appeal to the Latvians in the article was: "And we, like all other cultural nations, will not be able to ignore these issues, on which our better future will depend". ${ }^{2}$ Most likely, such testimony was the result of investigative pressure (as an example, one of Upners' interrogations - on 10 August - began at 9 p.m. and ended at 4 a.m.), and in this situation the researcher must carefully check all the testimonies during the investigation.

In the list of used literature, first of all, it is necessary to note studies devoted to the period of the Nazi occupation of

1 Upners' interrogation protocol on 20 September1948, LNA LSA, F. 1986, Descr. 2, Case P-6831, 23-27, here 24. 2 "Tautas nākotnes labā" [For the Future of the Nation], Tēvija, 1942, July 17,3. 
Latvia in general. Among these studies, in this case, the work of the Professor of the Uppsala University of Latvian origin, Haralds Biezais, should be highlighted, in which the issue of the powers and activities of the Latvian Land SelfGovernment (Landesselbstverwaltung) is considered in more detail. ${ }^{3}$ It is also worth noting here a collection of documents, which contains reports from Latvian circles in Stockholm about the Nazi occupation regime in Latvia for the information of the Allies and, first of all, the United States. ${ }^{4}$

The number of studies devoted to the history of eugenics in the interwar period in Latvia is quite large, especially considering that such studies could have appeared only after the restoration of Latvia's independence in 1991. One of the first here is a study published by Vita Zelce in 2006, which sets out both the reasons for the focus on eugenics in the 1930s and the main measures in its popularization and research. ${ }^{5}$ Further studies focused more on the biographical research of individual scholars through the prism of the history of science. Among them, we can mention an article by Jekabs Raipulis ${ }^{6}$ and a study on the scientific activities of Verners Kraulis. ${ }^{7}$ The list of these biographical studies also includes a monograph by Rita Gravere on Jekabs Primanis, one of the most prominent Latvian doctors and medical administrators, whose activities in 1930-1940 were closely linked with the development of eugenics in Latvia. ${ }^{8}$ Less often at this time, complex studies have been published, in which the development of the academic and research tradition of eugenics in Latvia was analyzed through the prism of the development of the University of Latvia or psychiatry. ${ }^{9}$ Unfortunately, the chronological framework of all these studies ends with the Soviet occupation of 1940, only mentioning, but not analyzing in more detail the events of the 1940s.

This chronological framework has been extended to 1945 in studies published outside Latvia, ${ }^{10}$ and Björn M. Felder's study deserves special attention here. ${ }^{11}$ The author of the study has collected and operates in his presentation with rich factual material, which is the undoubted value of this study. Some factual errors - for example, Dzems Raudzins was a lawyer, not an economist - are not of fundamental importance. However, the author of the mentioned study sometimes interprets the works of Latvian authors on eugenics too freely and does not always reasonably describe the position of Latvian doctors and researchers on racial hygiene issues. As just one example, we can cite the author's statement that in a book published in 1943 Upners advocated the compulsory sterilization of "inferior" people, ${ }^{12}$ although we cannot find such a call in the text of the book.

All of the above emphasizes the relevance of this study, the task of which is not only to supplement the factual material collected in previous studies, but also to try to more carefully assess the involvement of Latvian physicians in the implementation of the racial policy of the Nazi occupation regime in Latvia.

The main research method used in this study is the method of content analysis, analyzing and confronting facts and information from different sources. It is important, in this case, to consider each documentary source in the context of the time and circumstances of its appearance, since this undoubtedly influenced the content of these documents.

\section{Academic Tradition of Eugenics in Latvia}

Interest in the ideas of eugenics or good heredity in the Latvian academic community was already noticeable in the 1920 s, but as a practical scientific research direction, eugenics developed in the second half of the 1930s. The starting

3 Haralds Biezais, Latvija kāškrusta varā: Sveši kungi - pašu l̦audis [Latvia under Might of the Swastika: Foreign Rulers - Own People], (East Lansing: Gauja, 1992).

4 Andrew Ezergailis ed., Stockholm Documents: The German Occupation of Latvia, 1941-1945: What Did America Know?(Riga: Publishers of the Historical Institute of Latvia, 2002).

5 Vita Zelce, "Vara, zinātne, veselība un cilvēki: Eigenētika Latvijā 20. gs. 30. gados" [Power, Science, Health and People: Eugenics in Latvia in the 1930s], in Latvijas arhivi, 2006, Nr.3,94-138.

6 Jekabs Raipulis, "G̣enētikas studijas un pētījumi Latvijas Universitātē" [Studies and Investigations of Genetics at the University of Latvia], in Latvijas Universitātes Raksti: Zinātņu vēsture un muzejniecība, vol. 815(Riga: Latvijas Universitāte, 2017), 200-221.

7 Ieva Libiete, "Verners Kraulis (1904-1944) - spilgta personība Latvijas psihiatrijas vēsturē" [Verners Kraulis (19041944) - an Outstanding Figure in the History of Psychiatry in Latvia], in Latvijas Universitātes Raksti: Zinātñu vēsture un muzejniecība, vol. 780(Riga: Latvijas Universitāte, 2012), 182-195.

8 Rita Gravere, Tā mēs atgriežamies...: ārsts, anatoms, antropologs Jēkabs Prīmanis (1892-1971) [This is How We Return...: Doctor, Anatomist, Anthropologist Jekabs Primanis (1892-1971)], (Riga: Skaldu raksti, 2017).

9 Vladimir Kuznecov, "Latvian Psychiatry and Medical Legislation of the 1930s and the German Sterilisation Law," inBaltic Eugenics: Bio-Politics, Race and Nation in Interwar Estonia, Latvia and Lithuania 1918-1940. On the Boundary of Two Worlds: Identity, Freedom, and Moral Imagination in the Baltics, vol. 35, ed. Björn M.Felderand Paul J. Weindling (Amsterdam \& New York, Brill NY: Rodopi, 2013),147-168.

10 Marius Turdaed., The History of East-Central European Eugenics, 1900-1945: Sources and Commentaries, (London: Bloomsbury, 2015).

11 Björn M.Felder, "In Pursuit of Biological Purity: Eugenics and Racial Paradigms in Nazi-Occupied Latvia, 1941-1945," in Racial Science in Hitler's New Europe, 1938-1945, ed. AntonWeiss-Wendtand Rory Yeomans (University of Nebraska Press: Lincoln, NE, 2013),320-346.

12 Ibid.,332. 
point here was 1934, when the Department of Eugenics was established at the University of Latvia and its head, Privatdozent (Priv.-Doz.) Gustavs Reinhards (1868-1937), began to teach students a special course on eugenics. After Reinhards' death, the course of eugenics was continued by psychiatrist Verners Kraulis (1904-1944). The relevance of eugenics issues in the social processes of society was reflected in the section "Eugenics Commissions" of the Medical Treatment Law adopted in 1937. ${ }^{13}$ But concrete and locally material-based eugenics research in Latvia began after the Institute for Research of National Vitality (Tautas dzīva à spēka pētišsanas institūts) was founded in February 1938 at the Health Promotion Society. ${ }^{14}$ Professor of anatomy Jekabs Primanis (1892-1971) became the director of the institute. In a short time, the institute developed a vigorous activity both in promoting the ideas of increasing the "vitality of the people" in society (mainly focusing on increasing the birth rate and combating alcoholism), and in launching several research projects and publishing a collection of articles prepared by the institute in 1939. The possibilities of cinema were also used to popularize eugenics, and in March 1939 a film was shown for the first time about the work of a school for defective children in Riga. ${ }^{15}$ All of the above testifies to the fact that eugenics in the late 1930s already had a strong enough scientific and research tradition in Latvia. And it is important to emphasize that, in the general opinion, in the case of Latvia socalled 'positive' eugenics prevailed in the content of eugenics.

During the first Soviet occupation in 1940, there was a break in the development of eugenic research, and the first collection of articles published by the Institute for Research of National Vitality was included in the list of prohibited literature. ${ }^{16}$ Interestingly, according to some recollections, during the first Soviet occupation, the university continued to teach eugenics, ${ }^{17}$ but it is more likely that these recollections refer to a hygiene course taught by Victor Milenbahs (18981986). ${ }^{18}$

In 1941, with the beginning of the Nazi occupation, it could be expected that eugenics in Latvia would regain its status as a science based on its previous traditions. However, the new occupation authorities immediately made it clear that it would not allow academic freedom (a vivid illustration of this was the renaming of the University of Latvia into the University of Riga) ${ }^{19}$ and it has its own view of eugenics. The reorganization carried out by the Nazi occupation regime caused cardinal changes both in the content of eugenics and in the scientific direction of eugenic research in Latvia. Foremost, for various reasons, there were changes in the composition of the university lecturers: Kraulis was expelled from the university as being too loyal to the Soviet regime, and Docent Milenbahs, who, according to Upners during the 1948 investigation, also worked for two semesters in the field of eugenics at the university, quit this job in $1941 .{ }^{20}$ At the same time, at the end of 1941, news appeared in the press about the initiative to resume the Institute for Research of National Vitality. ${ }^{21}$ However, almost immediately the quality of this initiative was reduced, and under the authority of the Department of Health, a Working Group for the Promotion of National Vitality, headed by Dzems Raudzins (1910-1979),* was created. It was also planned to create a branch of eugenics under the Working Group. In this situation, when the more authoritative Latvian researchers in the field of eugenics were removed or stepped aside themselves, the scientific development of eugenics was entrusted to a new specialist neurologist Theodor Upners.

\section{Theodor Upners: From the Son of a Blacksmith to the Head of the Eugenics Branch}

Born into a rural blacksmith's family, Upners had started working on long-distance merchant ships at the age of 14.** With the outbreak of World War I, these ships began to supply military goods to Russia from abroad. In early 1918, Upners by ship "Vologda SS" had gone on his last voyage to Saint John, Canada, where the Canadian authorities confiscated the

13 "Ārstniecības likums"[Medical Treatment Law], Valdības Vēstnesis, 1937,December 28,1-4.

14 "Tautas dzīvā spēka pētī̌sanas institūts atklāj darbību" [The Institute for Research of National Vitality Opens Its Activities], Jaunākās Ziņas, 1938, February 9, 5.

15 "Apspriedīs tautas dzīvā spēka problēmu" [The Problem of National Vitality will be Discussed], Zemgales Balss, 1939, March 17, 4.

16 "Apḳīāti izdevumi" [Withdrawn Editions], PadomjuLatvija, 1940, August 12,5.

17 Libiete,"Verners Kraulis,"189.

18 Raimunds Pavasars, "Latviešu zinātnieka 80 mūža gadu" [80 Years of Life of a Latvian Scientist], Universitas, 1978, Nr. 42, 85-86.

19 Latvian Circles in Stockholm, "Conditions at the University of Rīga under the Soviet and German Occupations," in Stockholm Documents, ed. Ezergailis,369-373.

20 Upners' interrogation protocol on 10 August1948, LNA LSA, F. 1986, Descr.2, Case P-6831, 19-22, here 21.

21 "Padomi ǵimenes dzīves jautājumos"[Family Life Advice], Tēvija, 1941, December 27,2.

* Dzems Raudzins - mag. iur., born in 1910 in Harbin, China, an athlete, in 1935 as a member of the Latvian national team won the title of the first European basketball champion, in 1933 he participated in the student world football championship in Italy, headed the Working Group for the Promotion of National Vitality during the Nazi occupation, but came into a conflict with the Nazi authorities (according to one version, due to his patriotic views), was arrested and placed in the Salaspils concentration camp, after the war moved to Germany, later to Australia, where he died in 1979.

** The facts of Upners' biography mentioned here are taken from the records of his interrogation and other materials of the 1948 Investigation file. 
ship and sent sailors to Victoria Island. A few weeks later, the ship's crew was transported to Japan on a Japanese ship, from where Upners arrived in Vladivostok and returned to Latvia in 1920. Here he served in the Latvian army until 1934. During this time, he completed sanitary courses and became a paramedic, in 1926 - at the age of 28 - received a certificate of secondary school as an external student, and from 1927 to 1933 he studied at the Faculty of Medicine of the University of Latvia. After graduating from the University of Latvia, since 1933, Upners worked at the university as an assistant at the Department of Neurology, and in May 1939 he defended his thesis and received the degree of Doctor of Medical Sciences. In the fall of 1941, already during the Nazi occupation, Upners was awarded the degree of Priv.-Doz. for the scientific work presented. All this testified to Upners' purposefulness and efficiency, and in relation to him the wording is very precise: a person who created himself.

As Upners testified in the 1948 investigation, in January 1942 he had been summoned by Professor Primanis, Dean of the Faculty of Medicine of the University of Riga. ${ }^{22}$ According to Primanis, the Nazi occupation authorities demanded that for the students of the university a course on racial hygiene was taught, and Primanis suggested that Upners should do this. Upners turned down the offer because, he said, he considered the racial theory absurd. Then Primanis had offered him to teach a course of eugenics at the university, which Upners had agreed to. ${ }^{23}$ Immediately after that, on 10 January 1942 by the decision of the Director of the Health Department of the Latvian Land Self-Government, Upners was also confirmed as the head of the Eugenics Branch of the Working Group for the Promotion of National Vitality (already in 1942, the subordination and name of this institution changed, and it continued to work as the Division for the Promotion of National Vitality of the Social Department). Prior to that, that is, until 1942, Upners, according to him, did practically nothing in the field of eugenics, ${ }^{24}$ and he explained his appointment by the personnel changes that left the position of the leading specialist in eugenics vacant.

\section{Regime}

Upners' Participation in the Practical Implementation of the Eugenic Measures of the Nazi Occupation

According to Upners at the 1948 MGB investigation, his involvement in the practical implementation of the eugenic measures of the Nazi occupation regime was limited: for instance, on specific issues of sterilization of people, decisions were made by the Nazi authorities. ${ }^{25}$ The fact that there was no evidence to the contrary in the materials of the MGB investigation suggests that Upners' statement was true. Describing his role as the head of the Eugenics Branch in the development of eugenics policy in Latvia, Upners mentioned only one episode. In 1943, the Division for the Promotion of National Vitality was tasked with drafting a law that would define a procedure for newlyweds to submit documents before marriage stating that they do not have diseases according to eugenic indications. Upners and Raudzins drafted and presented such a bill at a meeting of the Department of the Interior, which was also attended by the head of the Department and the actual head of the Latvian Land Self-Government Oskars Dankers (1883-1965), but the consideration of the bill was postponed. Upon reconsideration of the bill, in which Upners was not participated, the bill was passed but subsequently rejected by the Nazi authorities, who deemed it premature due to a lack of staff and institutions needed to issue such documents to newlyweds. ${ }^{26}$

In addition, as head of the Eugenics Branch, Upners received orders and instructions on eugenics issues for information purposes. One such document, a copy of which was found in the Latvian language at Upners' in 1948, was the Rules of 27 April 1942 on the application of German law to German Subjects in the occupied Eastern territories. ${ }^{27}$ These rules, signed by the Reich Minister for the Occupied Eastern Territories Alfred Rosenberg (1893-1946) and Heinrich Himmler (1900-1945), Reichsführer-SS and the Reich Commissar for the Strengthening of German Ethnic Stock (Reichskommissar für die Festigung deutschen Volkstums), in the third paragraph stipulated that marriages between citizens of Germany and citizens of other nationalities, who on 22 June 1941 only had citizenship of the Soviet Union (USSR) and since then have not received any other citizenship, are prohibited in the occupied Eastern territories. Another

22 Upners' interrogation protocol on 10 August1948, LNA LSA, F. 1986, Descr.2, Case P-6831, 20.

23 In subsequent petitions for clemency and rehabilitation, filed by Upners' wife Valentina in 1953 and by Upners himself in 1989, the decision to invite Upners and his consent to teach the eugenics course was explained by the fact, that otherwise the teaching of the eugenics course would have been entrusted to some doctor from the Baltic Germans who had already returned to Riga; therefore, the Dean of the Faculty of Medicine of the university, Professor Primanis, had insisted that Upners take over the course,see: Valentina Upners' petition to pardon her husband to the Chairman of the Presidium of the Supreme Soviet of the USSR Kliment Voroshilov on 1 June1953, LNA LSA, F. 1986, Descr. 2, Case P-6831, 188-189.; Statement by Upners to the Chief Prosecutor of the Latvian SSR on February 1989, LNA LSA, F. 1986, Descr. 2, Case P6831, 327-333, here329.

24 This statement by Upners is confirmed by a list of scientific articles published by him, which is attached to the materials of the 1948 investigation, see:List of Upners' scientific publications, 1 September1948, LNA LSA, F. 1986, Descr. 2, Case P-6831, 153.

25 Upners' interrogation protocol on 27 September1948, LNA LSA, F. 1986, Descr.2, Case P-6831, 28-31, here 28. 26 Ibid.,28-29.

27 Copy of the Rules of April 27, 1942, on the application of German law to German Subjects in the occupied Eastern territories, LNA LSA, F. 1986, Descr. 2, Case P-6831, 141-144. 
document was the Comments on Article A/3076-23.09.42 of the Director General of the Office of Justice. ${ }^{28}$ In these comments, on the instructions of the Director General of the Office of Justice, proposals were formulated by the Division for the Promotion of National Vitality of the Social Department on the issue of marriages between prisoners of war and citizens of the Province General of Latvia (Generalbezirk Lettland). Referring to a number of arguments - the possible predominance of the Russian element in such marriages and the unclear past of prisoners of war - it was concluded that such marriages should, in principle, be prohibited. The legal basis for this could be the order of 28 September 1942 on the punishment of persons who knowingly maintain contacts with prisoners of war, but a specific statement about the refusal of such marriages was recognized as more preferable. As an argument, in such case, following the example of Germany, the explanation could be used that such marriages grossly offend the healthy feelings of the nation.

Particular attention in the 1948 investigation was paid to the issue of the practice of regulating marriage during the Nazi occupation in cases where one of the spouses was Jewish. According to Upners, in such cases, if a Jew was a husband, then he was sent to the ghetto, and if it was a wife, then the choice had to be made by the husband - if he wanted to continue living together, then the wife was sterilized, but if the husband did not want to continue living together, the wife was sent to the ghetto. ${ }^{29}$ As the only example known to him, Upners mentioned here the opera singer Mariss Vetra (19011965), whose wife was Jewish and had been sterilized (in 1944, Vetra and his family had gone to Sweden).

All three episodes in which Upners admitted his participation in decision-making with the practical application of eugenic measures date back to $1944 .^{30}$ In one case, it was a decision to allow a local Latvian woman to adopt a Russian girl from an orphanage. Two other episodes were related to the applications of Russian prisoners of war and Latvian women for permission to marry. In both cases, a special commission with the participation of Upners, referring to German law in this matter for the occupied Eastern territories, refused to issue a marriage license.

\section{Upners as a Theorist of Eugenics}

One of the main episodes of the indictment against Upners in the MGB investigation in 1948 was his trip to Germany in April 1942 to get acquainted with the practical organization of eugenic activities. According to Upners, the offer to go on a scientific trip to Germany was made by the Dean of the Medical Faculty of the university, Professor Primanis. ${ }^{31}$ In turn, at the suggestion of Upners, Munich was chosen as the purpose of the trip, where Upners had already worked at the German Institute for Psychiatric Research (Deutsche Forschungsanstalt für Psychiatrie) under Professor Ernst Rüdin (1874-1952) in 1936 and then in 1938, preparing a dissertation. The Nazi occupation authorities attached great importance to this trip, which, according to Upners, was evidenced by the fact that before the trip Upners was received by the Baltic German Harry Marnitz (1894-1984), head of the Department of Health and Human Care (Abteilung "Gesundheit und Volkspflege") at the General Commissioner of Latvia. Marnitz also issued a document to Upners, which indicated that he was travelling on a special mission and that all authorities should help him, and 1.5 thousand German marks. Upners had spent two months in Munich, where he got acquainted with the relevant literature and the organization of practical work at the City Health Department (Gesundheitsamt), which issued marriage permits. On the last two days of his scientific trip, he visited in Berlin Professor Günther Just (1892-1950), who headed the department of genetics at the research institute. $^{32}$

After returning to Latvia, Upners made several lectures on eugenics, which in the 1948 indictment were regarded as propaganda of Nazi racial theory and ideas of eugenics. In July 1942, Upners' interview about his impressions in Germany was published in the newspaper "Tēvija". ${ }^{33}$ In October 1942, before the start of the eugenics lecture course, Upners gave an introductory lecture to the university staff on public health from a eugenics perspective; in 1943 the text of this lecture was published in the journal "Ārstniecības žurnāls" ("Medical Journal"). ${ }^{34}$ However, as the main evidence of Upners' views during the Nazi occupation, the 1948 accusations cited a book he wrote and published in 1943.

The book "The Role of Eugenics in the Life of the Nation and the State" ("Eugenikas nozìme tautas un valsts dzīvē"), which, according to Upners, he wrote on the instructions of Raudzins, was published in Riga with a circulation of five thousand copies. The main charge in the 1948 investigation was based on the claim that in this book Upners glorified and popularized Nazi racial theory. Upners acknowledged this accusation, admitting that in the book he also called for a law on forced sterilization..$^{35}$ As an excuse for himself, Upners mentioned only one circumstance. According to him, the original version of the book had a more scientifically neutral content, but doctor Marnitz corrected the already written

28 Comments on Article A/3076-23.09.42 of the Director General of the Office of Justice on the issue of the marriage of prisoners of war, LNA LSA, F. 1986, Descr. 2, Case P-6831, 135-137.

29 Upners' interrogation protocol on 27 September1948, LNA LSA, F. 1986, Descr.2, Case P-6831, 28.

30 Ibid.,29.

31 Upners' interrogation protocol on 20 September1948, LNA LSA, F. 1986, Descr.2, Case P-6831, 23.

32 Ibid., 23-24.

33 "Tautas nākotnes labā,"Tēvija, 1942, July 17,3.

34 Theodor Upners, "Tautas veselība eigēniskā skatījumā" [People's Health from the Eugenics Perspective], Ārstniecības Žurnāls, 1943, Nr.3,197-202.

35 Upners' interrogation protocol on 20 September1948, LNA LSA, F. 1986, Descr.2, Case P-6831, 25. 
text, forcing him to emphasize on forced sterilization and the issuance of a corresponding law in Latvia. ${ }^{36}$ Therefore, Upners was forced to add text on German sterilization laws to the book.

In the foreword of the book, the author pointed out the danger of degeneration of cultural nations due to uneven birth rates in different social strata and the rapid growth in the number of genetically ill individuals.* As the purpose of the book, he formulated a proposal to reflect on these questions. In the first part of the book, Upners gave a brief overview of the principles and phenomena of genetics in nature. The second, more extensive part of the book was devoted to eugenics.

Having given a brief historical description of the emergence of eugenics, the author identified two main factors that threaten the development of peoples from the point of view of eugenics: low birth rate (which was also noted among Latvians) and the increased ability of "less hardy members of society" ("mazäk izturīgiem sabiedrības loceklliem") to reach a significant age and produce offspring as a result of medical advances. ${ }^{37}$ Noting both of these factors as a threat to future generations, Upners concluded that a distinction should be made between the right to life - which is for each individual and the right to give life. Therefore, in the place of natural selection in modern society must come conscious selection, i.e., eugenics. And to eliminate these threats, the destruction of 'low-value members of society' and even their absolute sterility is not required - a certain difference in fertility between different strata of society is enough. ${ }^{38}$

After describing the existing situation as he saw it, at the end of the book Upners formulated a program of measures that could correct this situation. To increase the birth rate in families of 'full-fledged members of society', he proposed a number of social measures: deductions from wages in childless families, benefits for families with children, housing and educational policies in support of large families. In turn, in the list of measures to limit the birth rate of 'low-value members of society', he mentioned mandatory medical examinations before marriage and the prohibition of marriage in case of certain diseases, as well as sterilization as the most radical method. Here Upners referred to the laws of several states of the United States, Swiss cantons and Denmark, however, highlighting as the broadest and most accurate 'Greater Germany's' Law for the Prevention of Offspring with Hereditary Diseases (Gesetz zur Verhütung erbkranken Nachwuchses) of 14 July 1933. As two of the most significant differences between this law and the laws of other countries, Upners noted the list of hereditary diseases named in the law for the application of sterilization, and the provision that also provided for forced sterilization. ${ }^{39}$

After reading this book, it must be admitted that, at least in this part, the charges against Upners in 1948 were unfounded. The issues discussed in the book are considered from the perspective of the development of the 'cultural peoples' and processes within nations, and not from the point of view of races, so Upners cannot be blamed for any popularization of the Nazi racial theory. Upners really speaks favourably about the 'Sterilisation Law' adopted in Germany, but with regard to Latvia he does not call for following this example: his calls are limited to the dissemination and explanation of eugenic ideas in Latvian society. ${ }^{40}$ In the context of the above, it seems strange that Upners admitted in the 1948 investigation that in his book he called for a law on forced sterilization in Latvia, although there is no such call in the book. It is possible that in this case Upners simply could not remember the content of his work, but even so, this does not indicate an objective investigation. ${ }^{41}$

The only public speech by Upners in which he spoke about eugenics in terms of racial politics was a lecture he gave in the fall of 1942 at a meeting of doctors and administrative leaders on the topic of improving the quality of national vitality. ${ }^{42}$ According to Upners, about 15 people had participated in the meeting, among them: Professor Primanis, Raudzins, Professor, Dr. Philos. Paul Jurevics (1891-1981), pastor and former head of the demographic division Klavs Silins (1904-1984), deputy director of the Department of Health Alexander Vitolins (1896-1959), pastor Alfred Goba (1905-1988) - chairman of the Anti-Alcohol Society, Heinrich Bosse Jr. - Baltic German, Marnitz' deputy. ${ }^{43}$ Here, in his lecture, Upners used formulations about "the problem of racial purity" and about "mixing of Aryan peoples with races of

36 Upners' interrogation protocol on 16 July1948, LNA LSA, F. 1986, Descr.2, Case P-6831, 15.

* One copy of the book is attached to the materials of the 1948 Investigation file.

37 Theodor Upners, Eugenikas nozime tautas un valsts dzīve [The Role of Eugenics in the Life of the Nation and the State], (Riga: Latvju Grāmata, 1943),22-23.

38 Ibid., 25-26.

39 Ibid.,57-61.

40 Ibid.,63-64.

41 In addition, partly the accusations against Upners were based on the manipulation of terms, which was clearly seen in the Russian translation of Upners' Latvian texts attached to the Investigation file; by way of illustration, the term "eugenics" used in Upners' article "The Health of the People from the point of view of Eugenics" has been replaced into translation by the term "racial hygiene", see:Upners' article "The Health of the People from the point of view of Eugenics"in the newspaper "Daugavas Vēstnesis" dated 25 November1942, and its Russian translation, LNA LSA, F. 1986, Descr. 2, Case P-6831, 90-91, 91a.

42 "Tautas dzīvā spēka kvalitātes celšana" [Improving the Quality of National Vitality], LNA LSA, F. 1986, Descr. 2, Case P-6831, 105-118.

43 Upners' interrogation protocol on 20 September1948, LNA LSA, F. 1986, Descr.2, Case P-6831, 27. 
little value". ${ }^{44}$ Here Upners spoke about the need for Latvians to be vigilant about the "purity of their race", taking care, if necessary, to issue appropriate laws. ${ }^{45}$ At the trial in 1948, Upners explained his speech by the instruction of Professor Primanis about the need to touch upon the issue of racial theory as well, and in the presence of Professor Bosse he could not refuse this. ${ }^{46}$ However, even in this lecture, we do not find Upners' calls for radical measures: the most far-reaching proposal that he puts forward at the end of the lecture is a call to discuss whether a separate law should be adopted in the future - perhaps, following the example of 'Greater Germany' - in order to fundamentally decide protection of future generations from hereditary diseases. ${ }^{47}$

Interestingly, while explaining his views on eugenics and racial theory at the 1948 investigation - at least according to the 10 August interrogation protocol - Upners transferred the goals of eugenics to the political sphere as well. According to him, eugenics, while declaring the determinant of heredity in human society, at the same time preaches the preservation of the old bourgeois order as a hereditary phenomenon, thereby justifying resistance to the revolutionary movement and new ways of development. ${ }^{48}$ Considering that such a view can be found only in one place in the Investigation file, it can be assumed that this idea did not belong to Upners himself, but was recorded on his behalf by an investigator of the MGB.

\section{The Results of the Investigation and Upners' Struggle for Rehabilitation}

Upners' Case was considered at a closed court hearing on 16 October 1948. He was accused of anti-Soviet agitation, praising 'Greater Germany' and glorifying Nazi racial theory. ${ }^{49}$ The court found Upners guilty, sentencing him to ten years imprisonment and five years of deprivation of rights. Upners was serving his sentence in Ukhta, Komi Autonomous Soviet Socialist Republic, working as a doctor in a hospital in a correctional labour camp. He was released from imprisonment on 23 May 1955 as having served $2 / 3$ of the sentence.

On 14 March 1967 Upners sent an application to the Prosecutor General of the USSR with a request to reconsider the Case for his complete rehabilitation..$^{50}$ On 23 May of the same year, the Prosecutor of the Latvian SSR, Vladimir Laivins (1923-1991), sent Upners' Case for verification to the Committee for State Security of the Latvian SSR ${ }^{51}$ In the conducted check, a review was received from an expert, Professor Janis Lusis, head of the Department of Zoology and Genetics of the Faculty of Biology, Latvian State University, about the published works of Upners on eugenics. In his review, Lusis, while positively assessing Upners' appeal to issues of heredity and his desire to spread this knowledge in society, at the same time criticized Upners' judgments about "inferior and valuable" individuals in society. ${ }^{52}$ Seventeen people were questioned as witnesses about Upners' activities during the Nazi occupation. Most of them - fourteen - were former students of the Faculty of Medicine of the University of Riga, who, with one exception, either poorly remembered the content of Upners' lectures, or characterized it as strictly medical. Only one former student described Upners' lectures as being held in the spirit of racial theory, noting that Upners had talked about preserving racial purity. Three other witnesses - a former colleague of Upners' at the university, his former patient and a nurse who served as the secretary of the medical commission for granting abortion permits during the Nazi occupation - described Upners as a good specialist. The final result of the check, formulated in the response of the Prosecutor to Upners, in the light of all the above mentioned testimonies, seemed somewhat unexpected: the verdict passed to him was recognized as correct and well-grounded. ${ }^{53}$

Upners made his last attempt at rehabilitation in February 1989, when he addressed an application to the Chief Prosecutor of the Latvian SSR. A year later, on 23 April 1990, the plenum of the Supreme Court of the Latvian SSR recognized the 1948 court verdict as unfounded and closed the Case against Upners due to the lack of corpus delicti.

\section{Results}

The Investigation file of the Ministry of State Security of the Latvian SSR against Upners is a set of documents in which views of different periods and different interests overlap. Therefore, when analyzing the Case materials, it is necessary to draw a clear distinction between two blocks of issues: the question of the political interests of the investigation and their implementation and the question of Upners' activities during the Nazi occupation.

The first thing that gives rise to speculation about the 'special' interests of the MGB investigation is the time of the initiation of the Case and Upners' arrest. Indeed, why did the scientist and doctor, whose activities were quite public during the Nazi occupation, continued to work freely in leading scientific and administrative positions for three years after the

44 "Tautas dzīvā spēka kvalitātes celšana,"LNA LSA, F. 1986, Descr.2, Case P-6831, 106.

45 Ibid., 107.

46 The minutes of the court session dated 16 October1948, LNA LSA, F. 1986, Descr. 2, Case P-6831, 177-181, here178. 47 "Tautas dzīvā spēka kvalitātes celšana,"LNA LSA, F. 1986, Descr.2, Case P-6831, 118.

48 Upners' interrogation protocol on 10 August 1948, LNA LSA, F. 1986, Descr.2, Case P-6831, 19.

49 Indictment in the Investigative case, 4 October 1948, LNA LSA, F. 1986, Descr. 2, Case P-6831, 161-164.

50 Statement by Upners to the Prosecutor General of the USSR on 14 March1967, LNA LSA, F. 1986, Descr. 2, Case P6831, 220-221.

51 Vladimir Laivins' order to the Chairman of theCommittee for State Security of the Latvian SSRon 23 May1967, LNA LSA, F. 1986, Descr. 2, Case P-6831, 219.

52 Review by Lusis of Upners' works dated 9 August1967, LNA LSA, F. 1986, Descr. 2, Case P-6831, 238-241, here241. 53 Statement byUpners to the Chief Prosecutor of the Latvian SSR on February 1989, LNA LSA, F. 1986, Descr.2, Case P-6831, 327-333, here 331. 
end of the war, and then suddenly he was charged with his previous activities? For a long time, Upners himself could not find an explanation for this, until in 1989, in his statement to the Chief Prosecutor of the Latvian SSR, he described himself a victim of the era of Trofim Lysenko (1898-1976), a critic of the 'bourgeois pseudoscience' of genetics. At the first moment, this judgment of his seem unfounded, but its correctness is partly confirmed by the review of Upners' book, attached to the materials of the 1948 investigation, given by Indrikis Zakis (1896-1970), head of the Department of Darwinism and Vice-Rector of the Latvian State University. In his review, Zakis directly referred to Lysenko's teachings, designating Upners' views as Social Darwinism. ${ }^{54}$ In the same context, Upners accused the 1948 investigation also of misunderstanding the fundamental difference between eugenics and racial hygiene, although even in Nazi Germany, according to him, there were two laws in this respect: Ehegesundheitsgesetz (Marriage Health Act) of 18 October 1935, and Blutschutzgesetz (Blood Protection Act) of 15 September 1935.55 All of the above allows us to conclude that the specific internal political situation in the USSR and political interests played a significant role in promoting the Upners' Case in $1948 .{ }^{56}$ Therefore, in 1967, when genetics had regained its scientific status in the USSR, the evaluation of Upners' activities had become much more moderate. However, the fact that the MGB's 1948 investigation was politically motivated does not in any way affect the answer to the question: How to evaluate Upners' activities during the Nazi occupation?

According to Upners' own judgments, his activities during the Nazi occupation were of a purely professional and scientific nature. The fact that he really did not see any guilt and reasons for possible repressions in his activities was evidenced by the fact that at the end of the war, with the advance of the Red Army, he did not leave for the West as a refugee and remained in Latvia. However, there were some dubious choices that did not correspond to the image of a professional and a scientist, and Upners himself understood this, finding various justifications for his actions. Describing his activity as a leading specialist in eugenics, Upners cited two arguments as an excuse. Firstly, Primanis convinced him to teach a course in eugenics at the university, motivating this by the desire to prevent the acceptance of some doctor of German origin for this position. There is no direct evidence to support Upners' statement of such an anti-German motive, but several factors, including the arrogant attitude of the Nazi occupation authorities towards the activities of the University of Latvia, make Upners' explanation quite plausible.

Secondly, talking of his work as the head of the Eugenics Branch of the Division for the Promotion of National Vitality of the Social Department, Upners pointed out that the decisive role in determining the policy of eugenics in Latvia yet was played by the Nazi administration. Upners talked about this in his testimony about decisions on marriage in cases where one of the spouses was a Jewish, and in testimony about the fate of the bill drawn up by him and rejected by the Nazi administration. This Upners' argument is indirectly confirmed by several studies, which discuss the issue of the rights and powers of the Latvian Land Self-Government. Controversial, in this case, was another aspect of this argument. In the aforementioned studies on the Latvian Land Self-Government, it is concluded that the Nazis needed the Land SelfGovernment as a cover that could cover up "with national shield all the misdeeds, crimes and mismanagement of the occupants". ${ }^{57}$ In this context, referring to the limited capacity of the eugenics branch and the fact that the practical decisions were made by the Nazi administration, Upners, in fact, admitted that the branch he headed, and he himself, was just such a cover for the Nazi administration, i.e. Upners allowed him to be used as such a cover.

However, the two most questionable decisions that cast a shadow on Upners' competence and decency as a scientist were his lecture in the fall of 1942 and the corrections he made to his book. His justifications by the situation and circumstances are humanly understandable, but for him as a scientist, this cannot be an excuse.

Assessing Upners' activities during the Nazi occupation as a whole, one can speak of him as a conformist and collaborator. His collaboration can be explained as a choice based on the principle of least evil, which in the historical experience of two world wars, two occupations and deportations of 1941 of Latvian society in the 20th century was a frequent choice of people. True, this does not diminish Upners' personal responsibility. But at the same time, however, it is unacceptable to attribute to Upners what he did not do - he did not call for the destruction or violent sterilization of any group of people.

54 Review by Zakis of Upners' book dated 30 September1948, LNA LSA, F. 1986, Descr. 2, Case P-6831, 145-148, here 146.

55 Statement byUpners to the Chief Prosecutor of the Latvian SSR on February 1989, LNA LSA, F. 1986, Descr. 2, Case P-6831, 331-332.

56 The Upners' Case once again acquired political relevance in 1952, when the MGB demanded to issue the Case materials from the archive due to investigative actions against a group of doctors, see:Inquiry from the Head of the MGB' Guard Division of the of the Latvia's Sea Basin, Lieutenant Colonel Zarubin, to the Deputy Head of Department "A" of the Ministry of State Security of the Latvian SSR, Lieutenant Colonel Verbovskiy, dated 1952.LNA LSA, F. 1986, Descr.2, Case P-6831, Surveillance' case, 45.

57 VoldemarsSalnais, "First Year of the German Occupation, 1942," inStockholm Documents, ed. Ezergailis, 11-109, here23. Haralds Biezais came to the same conclusion, referring to the Regulation on the Application of the Organizational Decree of the Ostland No. 2 (Durchführungsbestimmungen zum Organisationserlaß Ostland No. 2: Richtlinien für die Führung der Verwaltung im Generalbezirk Lettland), issued on 7 March1942, see: Biezais, Latvija kāškrusta varā, 59. 


\section{Discussion}

One of the most significant research problems in the history of World War II in Latvia is the issue of the participation and responsibility of Latvians in the implementation of the policy of the Nazi occupation regime. What makes it difficult to answer this question is the complicated understanding of cooperation in the situation in Latvia, where the independent state, lost in 1940, was first replaced by the Soviet occupation and then by the Nazi occupation in 1941. Historian Daina Bleiere in her study on the applicability of the concept of collaboration in the research of the Nazi occupation in Latvia, on the one hand, while recognizing the applicability of Stanley Hoffman's classification ${ }^{58}$ to Latvia in principle, at the same time, on the other hand, points out that direct comparison with other countries are not fruitful here. ${ }^{59}$ The same point of view is expressed by Andrew Ezergailis, an American historian of Latvian origin and researcher of the Holocaust, who indicates, just as the Nazi occupation was of different kinds, so there were different collaborations, and that he is negative about the applicability of the concept of collaboration to Eastern Europe in general and to Latvia in particular. And in this context, he formulates an important conclusion: "Collaboration in Eastern Europe and Latvia needs to be critically, not presumptively, established". ${ }^{0}$

All of the above also applies to the question of the role of Latvian scientists in the Nazi's eugenics policy in Latvia. The fact that Upners collaborated with the Nazi regime is an obvious truth. But never in his activities in the field of eugenics did Upners act as initiator, but only as performer. Moreover, if we accept Upners' version that he agreed to teach at the university in order to prevent the coming to this position of a doctor of German origin, then his collaboration acquires a kind of motive of resistance. The question remains here: does and how does this motive change the view of Upners' collaboration?

Another important issue concerns the role of Latvians in eugenics politics during the Nazi occupation: was it a "Latvian eugenics project" 61 or a Nazi eugenic project? If we talk about the theoretical content of eugenics, it would be important here to find out whether the development of eugenics in Latvia during the Nazi occupation was a continuation of the pre-war academic tradition of eugenics in Latvia or its break. According to the author of this study, this was undoubtedly a break, whose slogan of "racial purity" had no roots in the pre-war academic tradition of eugenics in Latvia. We also cannot talk about the leading role of the Latvian Land Self-Government in the practical measures of eugenics: as Upners testified, the last and decisive word belonged to the Nazi authorities. Therefore, it can reasonably be argued that the eugenics policy in Latvia during the Nazi occupation was primarily a Nazi eugenic project.

\section{Conclusions}

The materials of Theodor Upners' Investigation file show clearly enough that the development of eugenics in Latvia in the middle of the 20th century was subordinated to the interests of existing at that moment - Soviet or Nazi - political regime. Therefore, both during World War II and in the post-war years, it is not possible to talk about eugenics in Latvia outside the context of this political situation. Due to various circumstances, becoming formally the leading eugenicist in Latvia during the Nazi occupation, Upners tried to avoid transferring the ideas of the Nazi racial theory to Latvia as much as possible. Moreover, the fact that the same position was expressed by the Dean of the Faculty of Medicine, Jekabs Primanis, allows us to state that there were no convinced followers of the Nazi racial theory among Latvian academic scholars. Thus, we can argue that the eugenics policy implemented in Latvia during the Nazi occupation was not a "Latvian eugenic project", but primarily a Nazi eugenic project.

\section{Acknowledgements}

This article was written within the framework of the project "Interaction between the individual, the society and the state in process of the history of Latvia: conflicting values and formation of shared values during historical turning points" (project no. VPP-IZM-2018/1-0018).

\section{References}

[1] Haralds Biezais, Latvija kāškrusta varā: Sveši kungi - pašu l̦audis [Latvia under Might of the Swastika: Foreign Rulers - Own People], (East Lansing: Gauja, 1992).

[2] Daina Bleiere, "Par kolaborāciju: definīcijas, klasifikācija, pielietojamība vācu un padomju okupācijas pētniecībā Latvijā" [On Collaboration: Definitions, Classification and Application in Research Related to German and Soviet Occupation Regimes in Latvia], in Latvijas Vēstures Institūta Žurnāls, 2014, Nr.2, 139-167.

[3] Andrew Ezergailis, "Collaboration in German Occupied Latvia: Offered and Rejected", in Symposium of the

58 Stanley Hoffmann, "Collaborationism in France during World War II", in The Journal of Modern History, vol. 40, Nr.3 (Sep., 1968), 375-395.

59 Daina Bleiere, "Par kolaborāciju: definīcijas, klasifikācija, pielietojamība vācu un padomju okupācijas pētniecībā Latvijā" [On Collaboration: Definitions, Classification and Application in Research Related to German and Soviet Occupation Regimes in Latvia], in Latvijas Vēstures Institūta Žurnāls, 2014, Nr.2, 139-167, here 151.

60 Andrew Ezergailis, "Collaboration in German Occupied Latvia: Offered and Rejected", in Symposium of the Commission of the Historians of Latvia, vol. 11: Latvia Under Nazi German Occupation 1941-1945 (Riga: Institute of the History of Latvia Publishers, 2004), 119-140, here 119.

61 Felder, "In Pursuit of Biological Purity", 333. 
Commission of the Historians of Latvia, vol. 11: Latvia Under Nazi German Occupation 1941-1945 (Riga: Institute of the History of Latvia Publishers, 2004), 119-140.

[4] Andrew Ezergailis ed., Stockholm Documents: The German Occupation of Latvia, 1941-1945: What Did America Know? (Riga: Publishers of the Historical Institute of Latvia, 2002).

[5] Björn M. Felder, "In Pursuit of Biological Purity: Eugenics and Racial Paradigms in Nazi-Occupied Latvia, 1941 1945," in Racial Science in Hitler's New Europe, 1938-1945, ed. Anton Weiss-Wendt and Rory Yeomans (University of Nebraska Press: Lincoln, NE, 2013), 320-346.

[6] Rita Gravere, Tā mēs atgriežamies...: ārsts, anatoms, antropologs Jēkabs Prīmanis (1892-1971) [This is How We Return...: Doctor, Anatomist, Anthropologist Jekabs Primanis (1892-1971)], (Riga: Skaldu raksti, 2017).

[7] Stanley Hoffmann, "Collaborationism in France during World War II", in The Journal of Modern History, vol. 40, Nr.3 (Sep., 1968), 375-395.

[8] Investigative case of the Ministry of State Security of the Latvian SSR against Theodor Upners, LNA LSA, F. 1986, Descr. 2, Case P-6831.

[9] Vladimir Kuznecov, "Latvian Psychiatry and Medical Legislation of the 1930s and the German Sterilisation Law," in Baltic Eugenics: Bio-Politics, Race and Nation in Interwar Estonia, Latvia and Lithuania 1918-1940. On the Boundary of Two Worlds: Identity, Freedom, and Moral Imagination in the Baltics, vol. 35, ed. Björn M. Felder and Paul J. Weindling (Amsterdam \& New York, Brill NY: Rodopi, 2013), 147-168.

[10] Ieva Libiete, "Verners Kraulis (1904-1944) - spilgta personība Latvijas psihiatrijas vēsturē" [VernersKraulis (1904-1944) - an Outstanding Figure in the History of Psychiatry in Latvia], in Latvijas Universitātes Raksti: Zinātnuu vēsture un muzejniecība, vol. 780 (Riga: Latvijas Universitāte, 2012), 182-195.

[11] Raimunds Pavasars, "Latviešu zinātnieka 80 mūža gadu" [80 Years of Life of a Latvian Scientist], Universitas, 1978, Nr. 42, 85-86.

[12] Jekabs Raipulis, "G̣enētikas studijas un pētijumi Latvijas Universitātē" [Studies and Investigations of Genetics at the University of Latvia], in Latvijas Universitātes Raksti: Zinātṇu vēsture un muzejniecība, vol. 815 (Riga: Latvijas Universitāte, 2017), 200-221.

[13] Marius Turda ed., The History of East-Central European Eugenics, 1900-1945: Sources and Commentaries, (London: Bloomsbury, 2015).

[14] Theodor Upners, Eugenikas nozīme tautas un valsts dzīvē [The Role of Eugenics in the Life of the Nation and the State], (Riga: Latvju Grāmata, 1943).

[15] Theodor Upners, "Tautas veselība eigēniskā skatījumā" [People's Health from the Eugenics Perspective], Ārstniecības Žurnāls, 1943, Nr. 3, 197-202.

[16] Vita Zelce, "Vara, zinātne, veselība un cilvēki: Eigenētika Latvijā 20. gs. 30. gados" [Power, Science, Health and People: Eugenics in Latvia in the 1930s], in Latvijas arhīvi, 2006, Nr. 3, 94-138. 